\title{
Motion of Flexible Fibers in a Newtonian Flow
}

\section{Part 1: Discretization of Governing Equation, Outline of Computational Scheme and Numerical Solution in a Simple Shear Flow}

\author{
TAKEMURA Masashi*, CHIBA Kunji** and NAKAMURA Kiyoji*
}

*Department of Mechanophysics Engineering, Graduate School of Engineering, Osaka University, 2-1 Yamada-Oka, Suita, Osaka, 565-0871 Japan

**Faculty of Education, Shiga University, 2-5-1 Hiratsu, Otsu, Shiga, 520-0862 Japan

Received 18 December 2000; accepted for publication 8 May 2001

\begin{abstract}
The objective of this study is to well understand the interaction between the motion of flexible fibers and flow kinematics around the fibers in a Newtonian flow. In this framework, the evolution of the configuration of a single fiber in a simple shear flow was numerically calculated by the Peskin 'immersed boundary method'. Though a fiber can actually be deformed in three-dimensional way, the fiber was assumed simply to form a planar curve, and its configurational evolution was simulated for several cases different in fiber elasticity, fluid viscosity and shear rate.

In Part 1 of a series of papers, the underlying equations to describe the motion of the fiber and fluid were presented with their discretized forms necessary for calculation. Furthermore, how the fiber elasticity can affect the evolution of fiber configuration and flow kinematics was illustrated by a few examples. The results revealed that the fiber bending stiffness plays a key role both for the motion of a flexible fiber and for the flow field.
\end{abstract}

Key Words: Flexible fiber; Configuration of fiber; Evolution of flow kinematics; Immersed boundary method; Simple shear flow.

\section{ニュートン流体の流れ中におけるフレキシブル繊維の運動}

（第 1 報）基礎式の離散化と数值計算の手順および単純せん断流れ中における 数值計算結果

\section{竹村将志*, 千葉訓司**, 中村喜代次*}

\section{1. まえがき}

\section{流体中における繊維の運動は紡績や繊維強化複合材料} の成形などの工程で見られる重要な現象である．これら の工程では, 空気や高分子融液などの流れの中にある繊 維の運動を知り，それをうまくコントロールすることが 製品の品質や生産性を向上させる上で必要となる。

紡績工程に関連した繊維の運動に関しては千葉の研究 解説[1]にもあるように 1980 年代までに既に多くの 研究がなされ, 実験と数值計算の両面から各種の流れ中 における繊維の運動が明らかになっている.これに対し
て, 繊維強化複合材料の場合, 繊維の配向状態がその力 学特性を大きく左右することが知られており, ニュート ン流体の繊維懸濁液の複雑な流路内での流れならびに繊 維の配向の研究[2-13]が 1980 年後半から始められて いる. この研究分野は比較的新しい分野であるが, 緘維 含有率が小さい場合でも繊維眯濁液の流れ状態はニュー トン流体の場合と大きく異なることが明らかにされてお り, 今では, 繊維の配向状態と流れ場を連立して解く必 要があることが認識されている. しかし，実用的にはさ らに複雑な性質を有する高分子液体の繊維懸濁液の流れ ならびに繊維の配向 [14-19]を明らかにする必要があり，

** 連絡先: 滋賀大学教育学部 520-0862 大津市平津 2-5-1, Fax: 077-537-7840

* 大阪大学大学院工学研究科機械物理工学専攻 565-0871 吹田市山田丘 2-1 
これらの研究が最近徐々に行われるようになった.

上述した従来の研究では剛直な繊維を対象としており, 繊維の形態の変化と流れの相互干渉を考慮した研究はほ どんどない. すなわち, 流れによって繊維が変形すると 同時に, 繊維の形態の変化によって周りの流れ場が変わ ることを考慮に入れた研究は極めて少ない. ニュートン 流体の流れ中での剛直繊維の運動を計算する際によく用 いられている Jeffery[20]の方程式は, 繊維が運動しても 周りの流れは変化しないことを仮定して導かれている.

繊維と流れ場の相互干涉を考慮した計算が行われてい ない原因の一つとして考えられるのがコンピュータの計 算時間である. 纎維の形態の変化と流れ場の変化の相互 干渉を考慮して計算を行う場合, 各時間ごとに流れ場を 求めることが必要となる. そのため, ニュートン流体の 場合でも, 各時間で非線形の微分方程式である NavierStokes 方程式を解かなければならず，一般的に計算時間 が長くなる. しかし, 最近のコンピュータの発達ならび に数値計算法の開発によってこのような計算も比較的速 く行えるようになった.

本研究の目的は, 繊維と流れの相互干渉を考慮に入れ た数值計算を行い, ニュートン流体の流れ中におけるフ レキシブル繊維の運動とその周りの流れ場の変化を明ら かにすることにある．ここで用いる方法は，心臓内での 血液の流れを計算するために Peskin[21]により開発され た immersed boundary method である. この方法は, 細長 い水中動物の運動 [22] 队懸濁粒子の運動 [23, 24] の数値 計算などに応用されている．また，この方法を懸濁液内 でのフレキシブルな繊維の運動を取扱うために拡張する ことは比較的容易である [25]。ここでは, 一連の研究の 第一段階として，二次元単純せん断流れ場に一本の繊維 を懸濁した場合について, 緘維の運動とその周りの流れ 場を数值計算し, 繊維の弾性係数, 曲げ剛性, 粘度およ びせん断速度の影響を調べる.ただし, 繊維の変形はせ ん断流れの平面内でのみ考え, 3 次元変形は考えない. なお, 第 1 報では基礎式, 数值計算に必要な基礎式の離 散化, 計算手順について詳細に説明するとともに, 代表 的な計算結果を示すことにする.

\section{2. 基礎式}

まず, 2.1 節で, 繊維の分散媒である流体に関する基 礎式を示し, 次に, 2.2 節で, 繊維が流体に及ぼす力の 計算法 $[22,25]$ にいて示す.

\section{1 流れ場の基礎式}

非圧縮性のニュートン流体の流れ場を求める方程式は 連続の式と Navier-Stokes 方程式である.

$$
\nabla \cdot u=0
$$

$$
\rho \frac{D u}{D t}=-\nabla p+\mu \Delta u+F,
$$

ただし, $\boldsymbol{u}$ は流速, $\rho$ は流体の密度, $t$ は時間, $p$ は等 方圧力, $\mu$ は流体の粘度, $\boldsymbol{F}$ は流体に働く単位体積当 りの外力である.この外力は重力を無視し, 次節で示す 繊維の変形により生ずる力のみである. 各時刻において 繊維から受ける外力が分かると (1)，(2)式から次の時刻 における流れ場が計算できる.

\section{2 綞乘が流体に及ぼすカおよび織維の 運動に関する基樥式}

ここでは，(1) 繊維の体積は無視できるぐらい十分小 さい,（2）繊維の質量は無視する，(3) 繊維の変形は伸び 縮みと曲げ変形のみで, ねじり変形は生じない, (4) 重 力は無視する，(5) 瀻維はその十分近傍の流体と同じ速 度で移動する，と仮定する．なお，詳細は Fauci ら[22] ならびに Stockie ら [25]を参照すること.

\section{（a）繊維が流体に及ぼす力}

仮定より，流体に作用する外力 $\boldsymbol{F}$ は, 纎維の形状の 変化によって生じる力のみで, (3)式のように表せる.

$$
\boldsymbol{F}(\boldsymbol{x}, t)=\int_{\Gamma} f(s, t) \cdot \delta(\boldsymbol{x}-\boldsymbol{X}(s, t)) d s,
$$

ここで, $f$ は繊維の変形により生ずる力の線密度, $\Gamma$ は繊維の形態を表す曲線, $X(s, t)$ は繊維の座標， $x$ は 流れ場の座標, $s$ は $\Gamma$ 上の位置を示すパラメータ, $\delta$ は 二次元のデルタ関数であり, 3.2 節で示す (11.1), (11.2) 式を用いる.

また，力の線密度は(4)式のように繊維が変形するこ とによって蓄えられたエネルギ $E$ を $X$ で微分すること によって求められる.

$$
\boldsymbol{f}=-\frac{\partial E}{\partial \boldsymbol{X}},
$$

このときエネルギ $E$ は，「伸び縮み，曲げを考え，ねじ りは考えない」という仮定より (5) 式で与えられる.ま た，単位体積当たりに蓄えられる伸び縮みによるエネル ギ $E_{s}$ と，曲げによるエネルギ $E_{b}$ は，それぞれ (6.1), (6.2) 式で求める.

$$
E(X, t)=E_{s}(X, t)+E_{b}(X, t),
$$

$$
E_{s}(X, t)=\frac{1}{2} \sigma_{s} \int_{\Gamma}\left\{\left\|\frac{d X}{d s}\right\|-1\right\}^{2} d s
$$




$$
E_{b}(X, t)=\frac{1}{2} \sigma_{b} \int_{\Gamma}\left\{\frac{d^{2} \boldsymbol{X}}{d s^{2}} \cdot n-c(s, t)\right\}^{2} d s,
$$

ここで， $\sigma_{s}$ は弾性係数， $\sigma_{b}$ は曲げ剛性，\|\|は絶対值 を表し, $\boldsymbol{n}$ は緎維に立てた単位法線べクトルであり, $c(s, t)$ は繊維の自然状態での曲率である.

（b）繊維の運動と変形

繊維は流れによって移動, 変形するが,「繊維はその 十分近傍の流体と同じ速度で移動する」という仮定より, 繊維上の各位置 $\boldsymbol{X}$ の速度は(7)式となる.

$$
\frac{\partial X}{\partial t}=u(X(s, t), t)=\int_{\Omega} u(x, t) \cdot \delta(x-X(s, t)) d x,
$$

ここで, $\Omega$ は流れ領域を表す.

\section{3. 数值偖算法}

\section{1 流れ場の計算法}

2.1 節に示した Navier-Stokes 方程式を, 数値計算する ために離散化を行う，離散化には，差分の計算手法のひ とつである MAC 法(Marker-and-Cell method)を用い, 空 間分割にはスタガード格子を用いた. スタガード格子は, Fig.1 に示すように，圧力と外力成分をセル中央に，流 速成分をセル境界に配置したものである．このスタガー ド格子を用いることによって，数值振動を防ぐことが可 能となる.

まず， Navier-Stokes の方程式から圧力 $p$ に関する Poisson 方程式を導く. 既知の流速 $\boldsymbol{u}^{n}$ と外力 $\boldsymbol{F}^{n}$ を用い て, 次の時刻で連続の式を満たす条件の下で圧力に関す る Poisson 方程式を解いて現時刻における圧力 $p^{n}$ を求め る. 求めた圧力を用いて, 次の時刻での流速成分 $u^{n+1}=\left(u^{n+1}, v^{n+1}\right)$ を計算する. なお, 時間の差分スキー ムにはオイラーの陽解法を用いた。

\section{2 流体に及ほすすカおよび縤維の移動の 計算法}

全長 $L_{f}$ の繊維を $N_{f}$ 個の区間に分割し，両端を含め た $N_{f}+1$ 個の点の座標を $X_{l} \quad\left(l=0,1,2, \ldots, N_{f}\right)$ とし, また, $\Delta s=L_{f} / N_{f}$ とする (Fig.2 参照).

まず，伸び縮みのエネルギを表す(6.1) 式について考 える. (6.1) 式から

$$
E_{s}(X, t) \approx \frac{1}{2} \frac{\sigma_{s}}{\Delta s} \sum_{l=0}^{N_{f}-1}\left\{\left\|X_{l+1}-X_{l}\right\|-\Delta s\right\}^{2} .
$$

(8)式は, 繊維の隣り合った分割点の間をばねのよう に考え, その一つ一つに蓄えられたエネルギを繊維全体

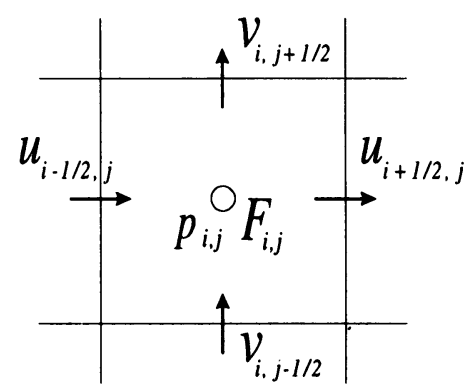

Fig.1 Staggered mesh for the marker-and-cell method.

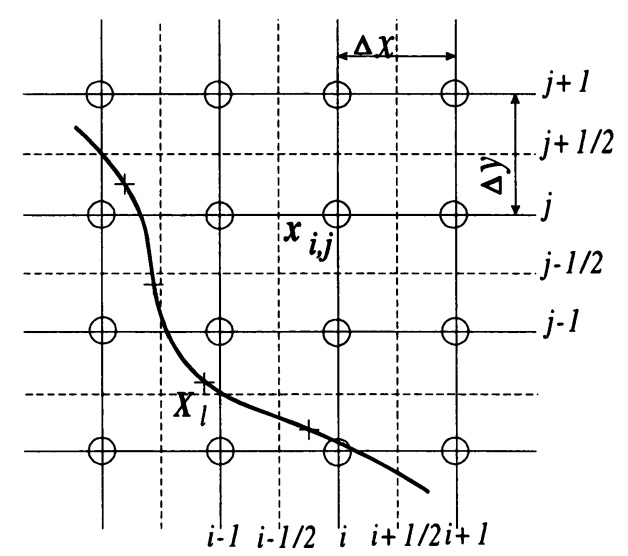

Fig.2 Relation between nodal points, $x_{i, j}$, in the computational domain and segmentation points, $\boldsymbol{X}_{l}$, on a fiber. These points are denoted by open circle and plus symbol, respectively.

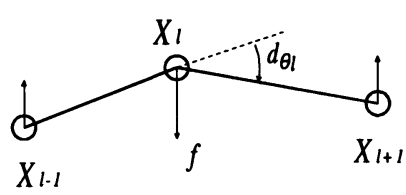

Fig.3 Link used to model a deformed elastic fiber.

で足し合わせたものが, 繊維全体に蓄えられた伸び縮み によるエネルギであることを表す．

つぎに，曲げによるエネルギを表す(6.2) 式について 考える.この式の被積分関数は, 繊維の曲率であり, Fig.3 に示すように $d \theta_{l}$ を定義すると，(6.2)式は

$$
\begin{aligned}
E_{b}(X, t) & \approx \frac{1}{2} \frac{\sigma_{b}}{(\Delta s)^{5}} \\
& \sum_{l=1}^{N_{f}-1}\left\{\left\|X_{l+1}-X_{l}\right\| \cdot\left\|X_{l}-X_{l-1}\right\| \sin d \theta_{l}-C(s, t)\right\}^{2}
\end{aligned}
$$

と離散化される（付録参照のこと）. ただし， $C(s, t)=$ $(\Delta s)^{3} c(s, t)$ である. 次に, 纎維の分割点 $X_{l}$ における力 の線密度 $f_{l}$ を求めるには, (4) 式に示したように全エネ 
ルギを微分すればよい．この力の線密度を用いて，(3) 式を離散化した次式により Fig.2 の格子点 $\boldsymbol{x}_{i, j}$ にある流 体要素に及ぼす力が計算できる.

$$
\boldsymbol{F}_{i, j}^{n}=\sum_{l=0}^{N_{f}} \boldsymbol{f}_{l}^{n} \cdot \delta\left(\boldsymbol{x}_{i, j}-\boldsymbol{X}_{l}^{n}\right) \cdot \Delta s .
$$

このときの二次元のデルタ関数は, Stockie ら [25]の 方法に従い,

$$
\begin{aligned}
& \delta\left(x_{i}, y_{j}\right)=d\left(x_{i}\right) \cdot d\left(y_{j}\right), \\
& d(r)=\left\{\begin{array}{cc}
\frac{1}{4 h}\left(1+\cos \frac{\pi r}{2 h}\right), & |r|<2 h \\
0, & |r| \geq 2 h
\end{array},\right.
\end{aligned}
$$

を用いる.ここで $h$ は，流れ場を分割したときの格子幅 で Fig.2では $\Delta x$ または $\Delta y$ である.

次に, 繊維の座標を更新する(7)式については,

$$
\boldsymbol{X}_{l}^{n+1}=\boldsymbol{X}_{l}^{n}+\Delta t \cdot \sum_{i, j} \boldsymbol{u}_{i, j}^{n+1} \cdot \delta\left(\boldsymbol{x}_{i, j}-\boldsymbol{X}_{l}^{n}\right) \cdot \Delta x \cdot \Delta y,
$$

と離散化して, 次の時刻での繊維の分割点の座標を計算 する.

\section{3 流速および圧力の境界条件}

（a）壁面境界条件

Fig.4 に示寸領域で計算を行う， $\Omega$ は流れ場を表し, $\Gamma$ は繊維の形状を表している, 計算領域は長さ $L_{x}$, 幅 $L_{y}$ でそれぞれ $N_{x}, N_{y}$ 個に分割する。 なお，流路壁面方 向を $x$ 方向, 幅方向を $y$ 方向とする. ここでは, 単純せ ん断流れ中における繊維の運動を取り扱うので, 壁面上 の流速成分はそれぞれ，

$$
u_{t}=-U, u_{b}=U, v_{t}=0, v_{b}=0,
$$

となる.ここで，Uは壁面が移動する速さ， $u_{t}$ と $u_{b}$ な らびに $v_{t}$ と $v_{b}$ はそれぞれ流路の上下壁面上での $x$ 方向

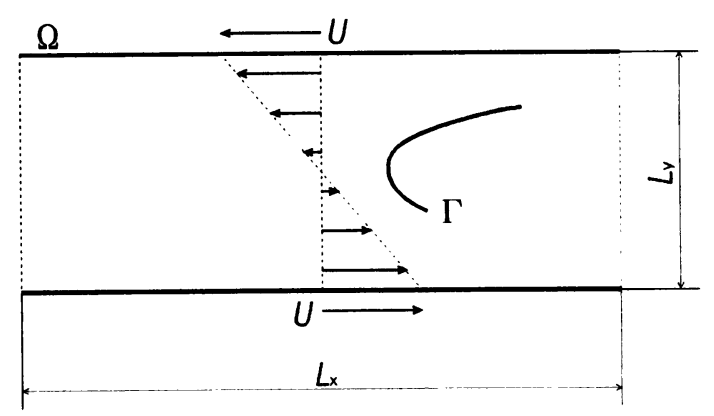

Fig.4 Computational domain, simple shear flow, and fiber configuration.
流速および y 方向流速である．また，圧力の壁面境界条 件は Navier-Stokes の方程式から次のようになる.

$$
\frac{\partial p}{\partial y}=\mu \frac{\partial^{2} v}{\partial y^{2}} .
$$

この式を上下壁面にそれぞれ適用して離散化したもの を数值計算に用いる.

（b）出入口境界条件

出入口では，流れは十分に発達し単純せん断流れにな っていると仮定し，流速に対しては次のような条件を与 える.

$$
\frac{\partial u}{\partial x}=0, \quad v=0 .
$$

一方，単純せん断流れにおいては，(14)式から，

$$
\partial p / \partial y=0,
$$

すなわち，圧力は幅方向にある任意の值で一定になるこ とから, 数值計算では $p_{0, j}=0, p_{N_{x}+1, j}=0$ のように, 境 界の一つ外側のセルで 0 という条件を与えた.

\section{4 数値計算手順}

以上示した離散化した式を用いて計算を行う手順につ いて述べる.

1. 繊維の分割点の座標 $\boldsymbol{X}_{l}^{n}$ より，(8), (9) 式を用いて, 各分割点で伸び縮みのエネルギ $E_{s}^{n}$ と曲げによるエネ ルギ $E_{b}^{n}$ を求める.

2. 䋐維に蓄えられているエネルギよりカの線密度 $f_{l}^{n}$ を 求める.この $\boldsymbol{f}_{l}^{n}$ から，(10)式を用いて，流れ場に働 く外力 $\boldsymbol{F}_{i, j}^{n}$ を求める.

3. 既知の流速 $u_{i, j}^{n}, v_{i, j}^{n}$ と, 今求めた外力 $F_{i, j}^{n}$ から, 圧力 に関する Poisson の方程式を解いて $p_{i, j}^{n}$ を求める.

4. $u_{i, j}^{n}, v_{i, j}^{n}, F_{i, j}^{n}, p_{i, j}^{n}$ を用いて, Navier-Stokes の方程式 を数値計算して, 次の時刻の流速 $u_{i, j}^{n+1}, v_{i, j}^{n+1}$ を求める.

5. $u_{i, j}^{n+1}, v_{i, j}^{n+1}$ より，(12) 式を用いて, 次の時刻の瀻維の 座標 $\boldsymbol{X}_{1}^{n+1}$ を求める.

6. 以上の手順を繰り返し行う.

このように瀻維の変形と流れ場の変化を交互に計 算することによって, 瀻維と流れ場の相互干涉の様 子を解析することができる.

\section{4. 数值計算結果}

ここでは, 弾性係数, 曲げ剛性, せん断速度ならびに 流体の粘度を変化して行った数值計算のうち, 代表的な 計算例について示し, 詳細は第 2 報で述べることにする.

計算条件は次の通りである。流れ場の長さ $L_{x}=9.0 \mathrm{~mm}$, 流れ場の幅 $L_{y}=3.0 \mathrm{~mm}$, 流れ場の分割数 


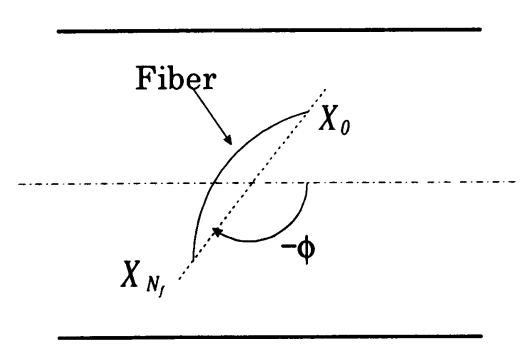

Fig.5 Definition of the inclination angle of a fiber, $\phi$.

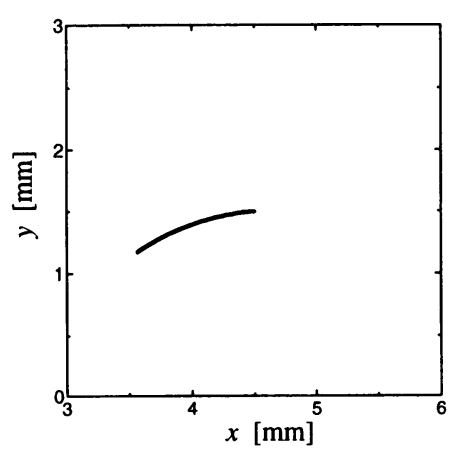

Fig.7 Initial position and curvature of a fiber used in the computations for examining the effect of bending stiffness.

$N_{x}=90, N_{y}=30$, 繊維の自然長 $L_{f}=1.0 \mathrm{~mm}$, 繊維の 分割数 $N_{f}=20$, せん断速度 $G=10 \mathrm{~s}^{-1}$, 流体の密度 $\rho=1.0 \times 10^{-6} \mathrm{~kg} / \mathrm{mm}^{3}$, 粘 度 $\mu=1.0 \times 10^{-4} \mathrm{~kg} / \mathrm{mm} \cdot \mathrm{s}$ $(0.1 \mathrm{~Pa} \cdot \mathrm{s})$ ，時間ステップ $\Delta t=5.0 \times 10^{-6} \mathrm{~s}$.また，自然 状態での繊維の曲率は 0 である.

\section{1 織維の伸長に及ほすす弾性係数の影霬}

弾性係数によって繊維がどの程度伸び縮みするのかを 調べるため, 曲げ剛性が $\sigma_{b}=7.5 \times 10^{-5} \mathrm{~kg} \cdot \mathrm{mm}^{3} / \mathrm{s}^{2}$ と $\sigma_{b}=6.25 \times 10^{-3} \mathrm{~kg} \cdot \mathrm{mm}^{3} / \mathrm{s}^{2}$ の 2 種類について, 弾性係数 を $\sigma_{s}=0.5,1.0,5.0,10.0 \mathrm{~kg} / \mathrm{mm} \cdot \mathrm{s}^{2}$ と変化させて計算を 行った.

初め, 緎維は曲率 0 で, 流れに対して $\phi=-17 \pi / 18$ 傾 けてあり, その重心は計算領域の中心である $x=4.5 \mathrm{~mm}$, $y=1.5 \mathrm{~mm}$ に位置する. 曲がっている緘維の角度 $\phi$ の定 義を Fig.5 に示す. $\phi$ は反時計回りを正とする.ここで 得られた計算結果より, 各時間の繊維の長さ $L$ を求め, 繊維の自然長 $L_{f}$ を用いて

$$
\varepsilon=\frac{L-L_{f}}{L_{f}},
$$

で定義される伸長ひずみ $\varepsilon$ を計算し， $\varepsilon$ の時間に対する 変化を Fig.6(a), (b)に示す.

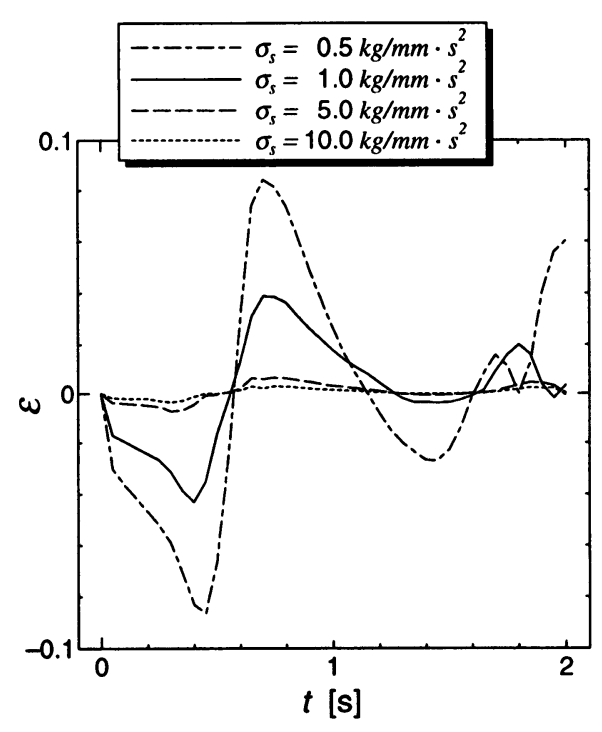

(a)

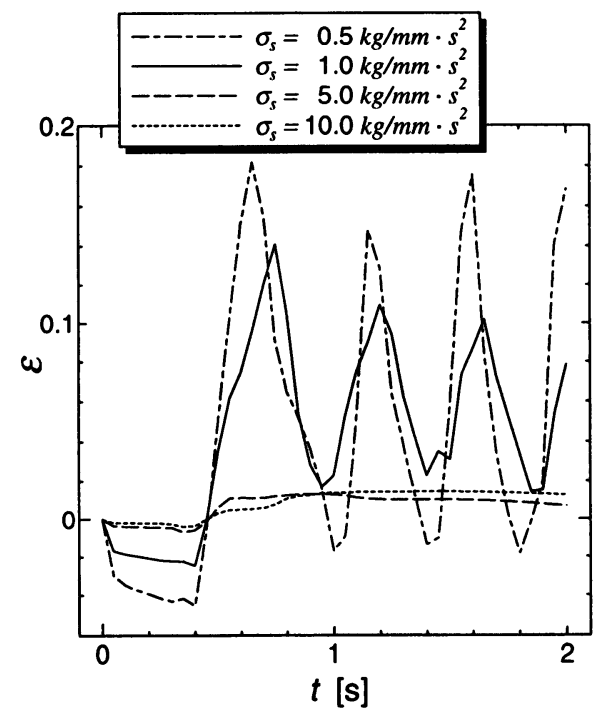

(b)

Fig.6 Effect of the elastic stiffness of a fiber $\sigma_{s}$ on the evolution of the extensional strain $\varepsilon$ for (a) $\sigma_{b}=7.5 \times 10^{-5}$ $\mathrm{kg} \cdot \mathrm{mm}^{3} / \mathrm{s}^{2}$; (b) $\sigma_{b}=6.25 \times 10^{-3} \mathrm{~kg} \cdot \mathrm{mm}^{3} / \mathrm{s}^{2}$; for $\mu=$ $1.0 \times 10^{-4} \mathrm{~kg} / \mathrm{mm} \cdot \mathrm{s}$ and $G=10 \mathrm{~s}^{-1}$.

どちらの曲げ剛性の場合も, 弾性係数が大きくなるに つれて, $\varepsilon$ の值が小さくなっていき， $\sigma_{s}=5.0$ と $10.0 \mathrm{~kg} / \mathrm{mm} \cdot \mathrm{s}^{2}$ の時には, 伸長ひずみは自然長の $2 \%$ 以 下になっている. また, 曲げ剛性が大きいときの方が伸 長ひずみは大きくなることも分かる.

次節では, $\sigma_{b}=7.5 \times 10^{-5} \mathrm{~kg} \cdot \mathrm{mm}^{3} / \mathrm{s}^{2}$ で最大 $5 \%$ 程度, $\sigma_{b}=6.25 \times 10^{-3} \mathrm{~kg} \cdot \mathrm{mm}^{3} / \mathrm{s}^{2}$ で最大 $10 \%$ 前後伸び縮みす る弾性係数 $\sigma_{s}=1.0 \mathrm{~kg} / \mathrm{mm} \cdot \mathrm{s}^{2}$ で計算を行う. 


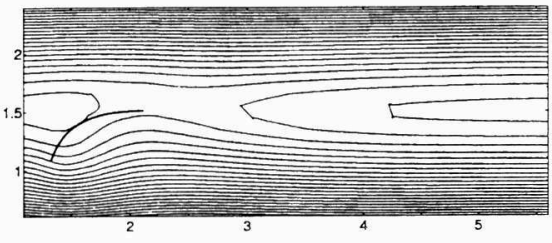

(1) $t=0.1[s]$

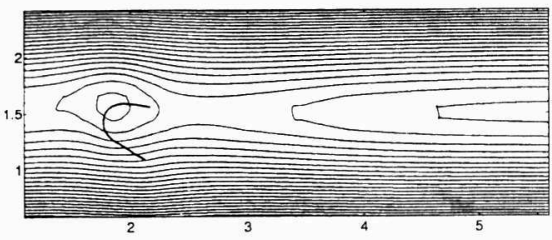

(2) $t=0.3[s]$

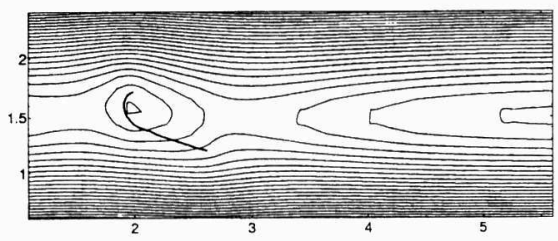

(3) $t=0.5[s]$

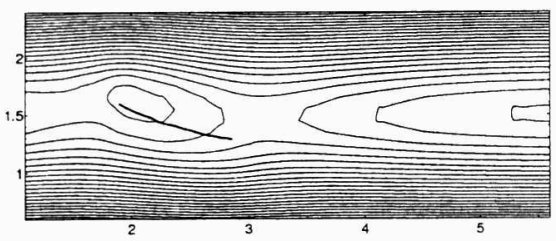

(4) $t=0.7[\mathrm{~s}]$

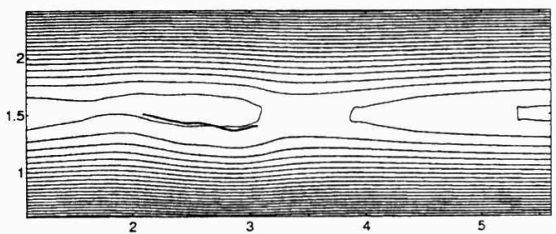

(5) $t=1.0[s]$

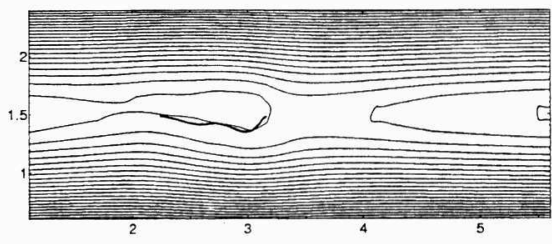

(6) $t=1.2[s]$

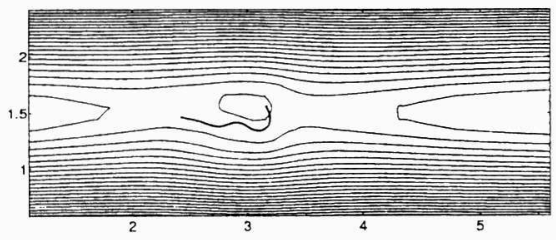

(7) $t=1.4[s]$

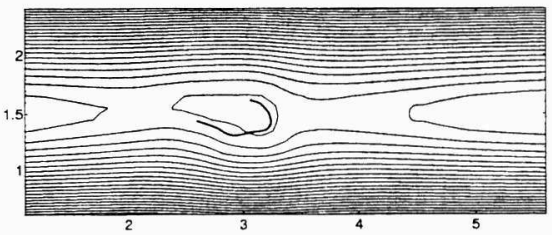

(8) $t=1.6[s]$

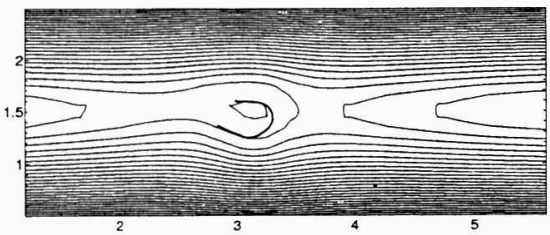

(9) $t=1.8[\mathrm{~s}]$

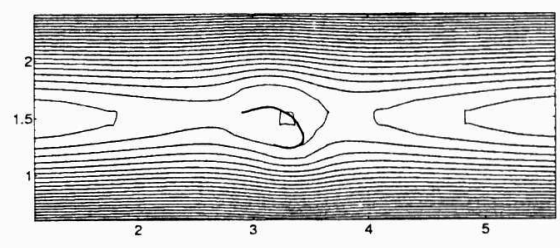

(10) $t=2.0[s]$

Fig.8 Evolution of streamlines and fiber configuration for $\sigma_{b}=7.5 \times 10^{-5} \mathrm{~kg} \cdot \mathrm{mm}^{3} / \mathrm{s}^{2}, \sigma_{s}=1.0 \mathrm{~kg} / \mathrm{mm} \cdot \mathrm{s}^{2}$, $\mu=1.0 \times 10^{-4} \mathrm{~kg} / \mathrm{mm} \cdot \mathrm{s}$ and $G=10 \mathrm{~s}^{-1}$. The initial position $\left(x_{0}, y_{0}\right)$ of the endpoint of a fiber is $(2.0 \mathrm{~mm}, 1.5 \mathrm{~mm})$. 


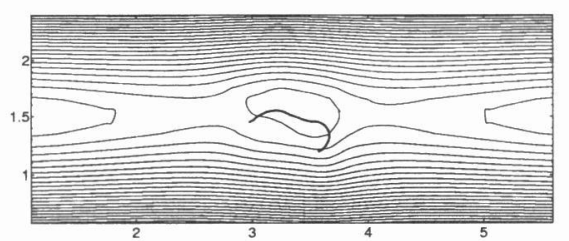

(11) $t=2.2[s]$

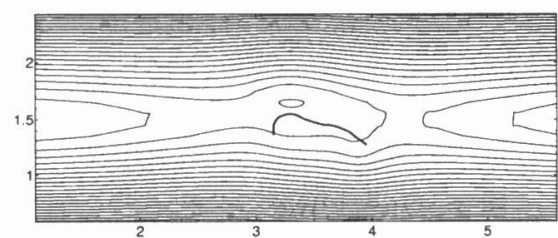

(12) $t=2.4[s]$

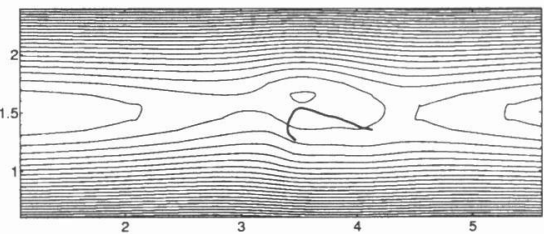

(13) $t=2.6[s]$

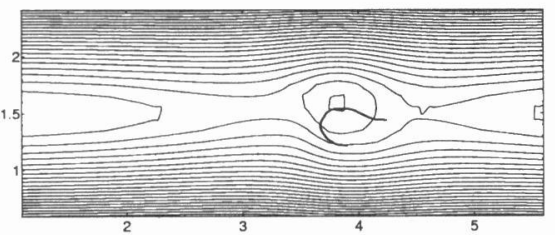

(14) $t=2.8[\mathrm{~s}]$

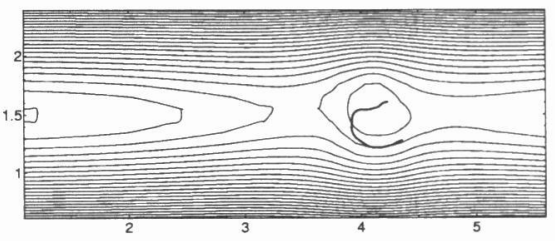

(15) $t=3.0[\mathrm{~s}]$

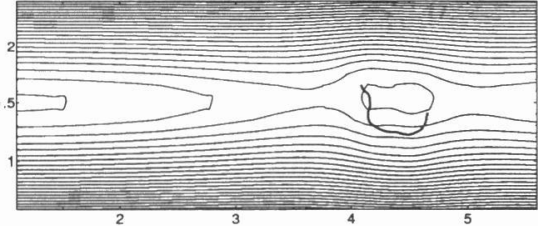

(16) $t=3.2[s]$

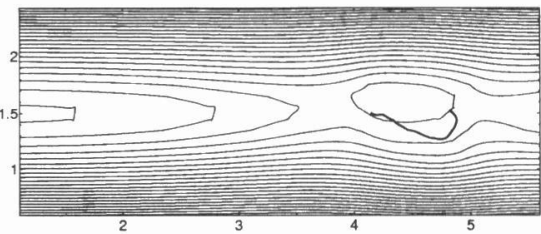

(17) $t=3.4[s]$

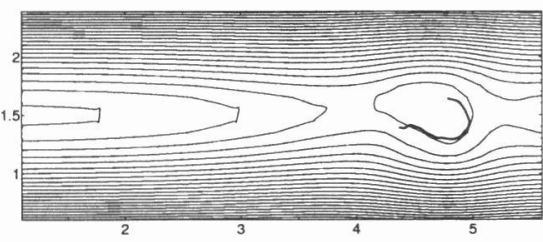

(18) $t=3.6[s]$

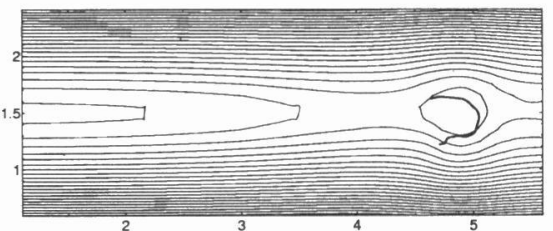

(19) $t=3.8[s]$

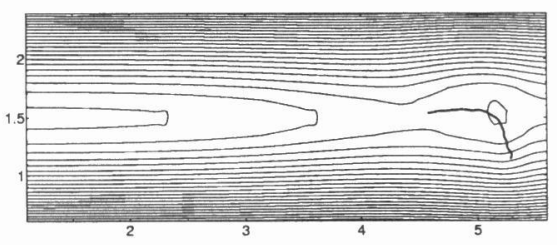

(20) $t=4.0[s]$

Fig.8 (continued) 


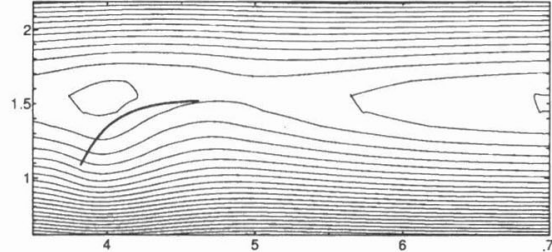

(1) $t=0.1[s]$

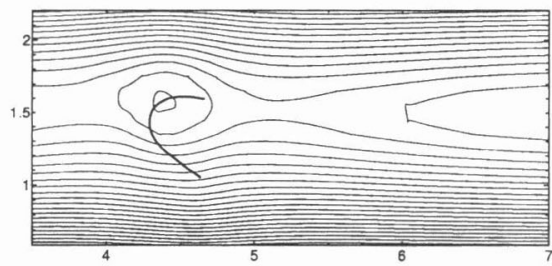

(2) $t=0.3[s]$

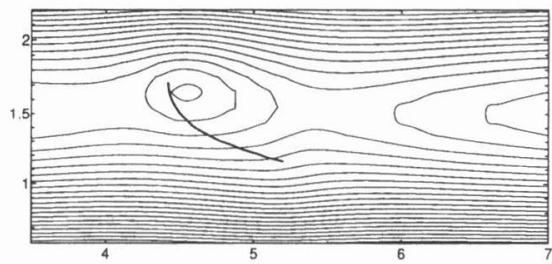

(3) $t=0.5[s]$

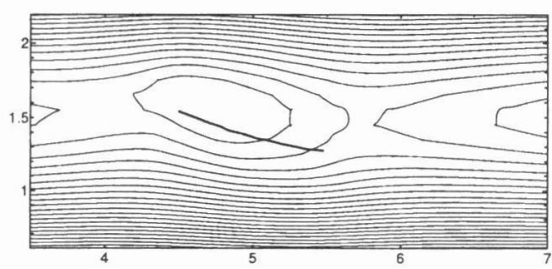

(4) $t=0.7[s]$

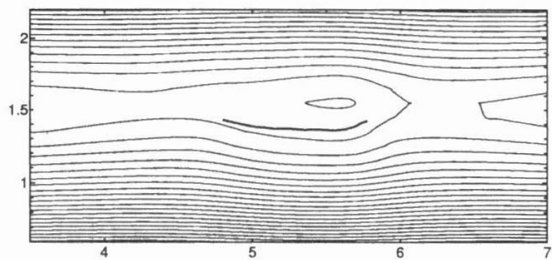

(5) $t=1.0[s]$

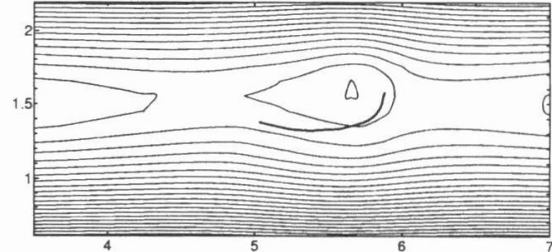

(6) $t=1.2[s]$

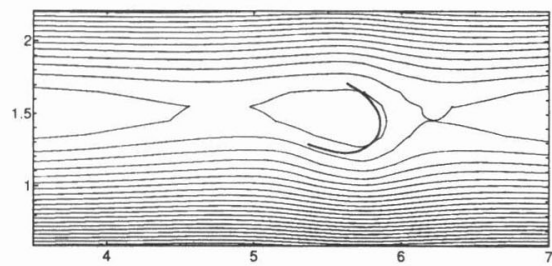

(7) $t=1.4[s]$

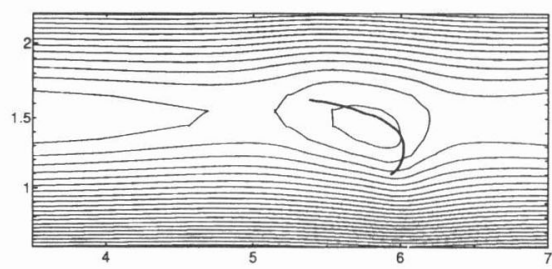

(8) $t=1.6[s]$

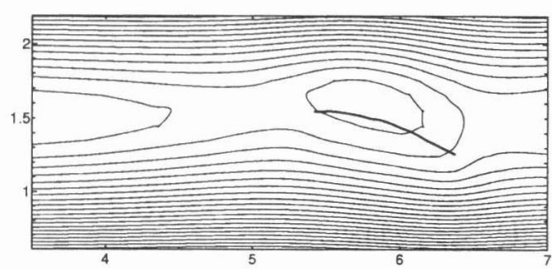

(9) $t=1.8[s]$

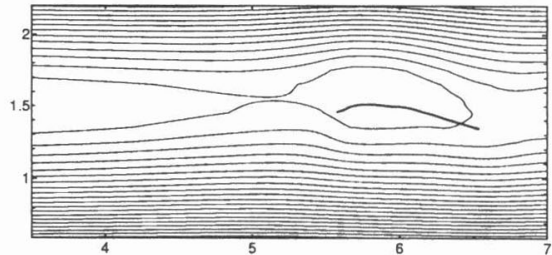

(10) $t=2.0[s]$

Fig.9 Evolution of streamlines and fiber configuration for $\sigma_{b}=5.0 \times 10^{-4} \mathrm{~kg} \cdot \mathrm{mm}^{3} / \mathrm{s}^{2}, \sigma_{s}=1.0 \mathrm{~kg} / \mathrm{mm} \cdot \mathrm{s}^{2}$, $\mu=1.0 \times 10^{-4} \mathrm{~kg} / \mathrm{mm} \cdot \mathrm{s}$ and $G=10 \mathrm{~s}^{-1}$. The initial position $\left(x_{0}, y_{0}\right)$ of the endpoint of a fiber is $(4.5 \mathrm{~mm}, 1.5 \mathrm{~mm})$. 


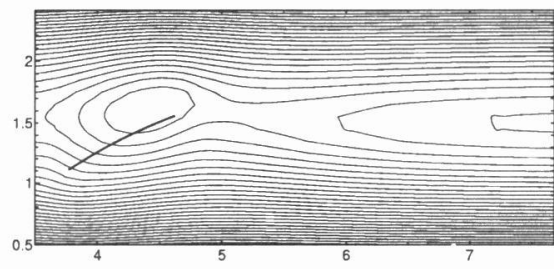

(1) $t=0.1[s]$

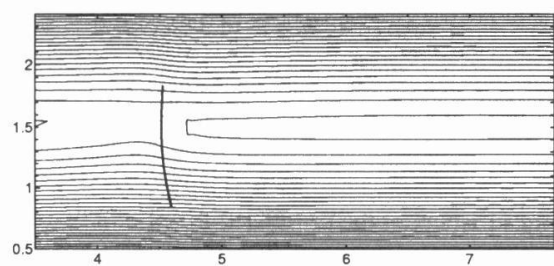

(2) $t=0.3[s]$

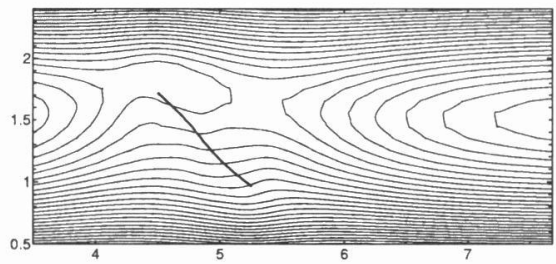

(3) $t=0.5[\mathrm{~s}$

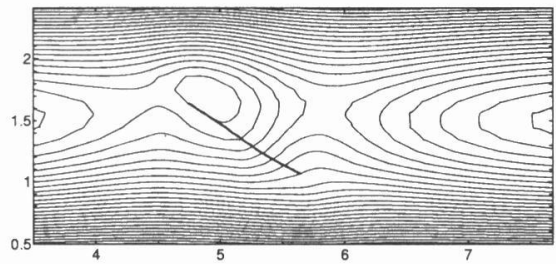

(4) $t=0.7[\mathrm{~s}]$

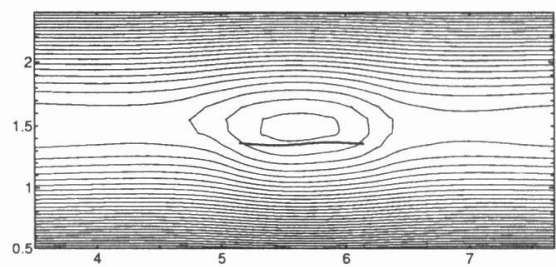

(5) $t=1.0[s]$

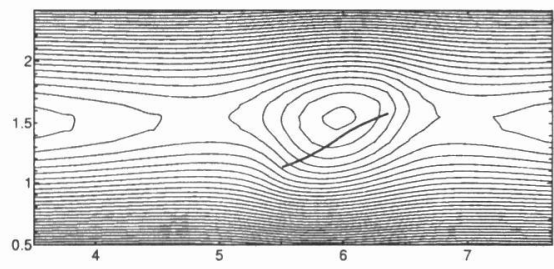

(6) $t=1.2[s]$

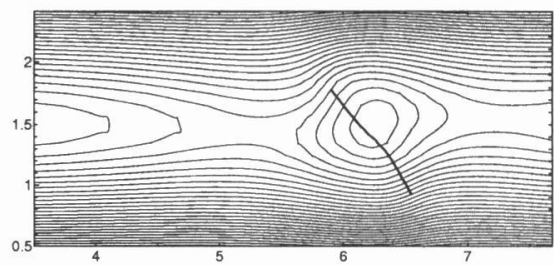

(7) $t=1.4[s]$

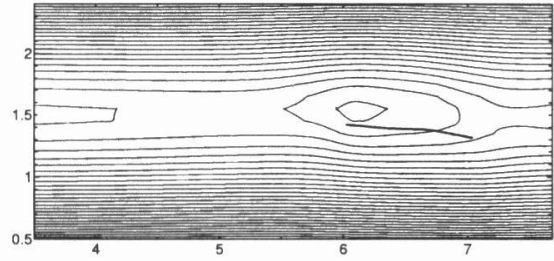

(8) $t=1.6[s]$

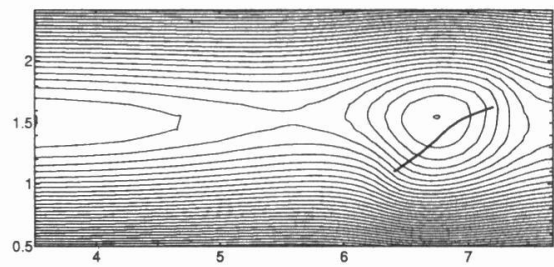

(9) $t=1.8[s]$

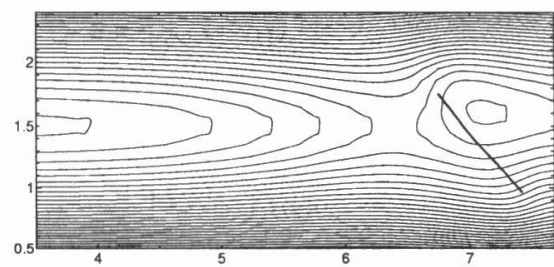

(10) $t=2.0[s]$

Fig.10 Evolution of streamlines and fiber configuration for $\sigma_{b}=6.25 \times 10^{-3} \mathrm{~kg} \cdot \mathrm{mm}^{3} / \mathrm{s}^{2} \quad \sigma_{s}=1.0 \mathrm{~kg} / \mathrm{mm} \cdot \mathrm{s}^{2}$, $\mu=1.0 \times 10^{-4} \mathrm{~kg} / \mathrm{mm} \cdot \mathrm{s}$ and $G=10 \mathrm{~s}^{-1}$. The initial position $\left(x_{0}, y_{0}\right)$ of the endpoint of a fiber is $(4.5 \mathrm{~mm}, 1.5 \mathrm{~mm})$. 


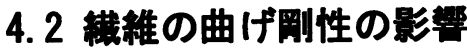

曲げ剛性の值だけを $\sigma_{b}=7.5 \times 10^{-5}, 5.0 \times 10^{-4}, 2.5 \times$ $10^{-3}, 5.0 \times 10^{-3}, 6.25 \times 10^{-3} \mathrm{~kg} \cdot \mathrm{mm}^{3} / \mathrm{s}^{2}$ と変化させて計 算を行った。代表的な計算結果を Fig.8 10 に示す. これ らの図には，各時刻での流線とそのときの䋐維の形状が 描かれており, 䌩維形状の変化と流れ場の変化の相互干 渉の様子が明確になる．なお，計算を行った際の繊維の 初期位置と初期形状は Fig.7 に示す通りであり, 繊維の 一端が $x=4.5 \mathrm{~mm}, y=1.5 \mathrm{~mm}$ に位置し, 曲率は $5.0 \times$ $10^{-1} \mathrm{~mm}^{-1}$ である. ただし，Fig.8 の場合には，初期位置 は $x$ 方向に $-2.5 \mathrm{~mm}$ 移動した $x_{0}=2.0 \mathrm{~mm}, y_{0}=1.5 \mathrm{~mm}$ である.初め繊維を流路幅方向のどこに置くかによって その後の緎維の変形状態ならびに流れ場が大きな影響を 受ける.もし繊維の重心を流路の中心軸上に置くと, Fig.4 に示すような単純せん断流れであるため, 緘維の形状は 重心に関して点対称に近い状態になり一般的でない。 こ こでは, 代表的な計算結果を示すことが目的であるので 瀻維の初期位置を流路中心軸から少し下の方へ移動した.

これらの図から，繊維の周辺には循環流れが発生し， その循環流れによって繊維が回転しながら下流へ移動す る様子が分かる．また，Fig.10に示す $\sigma_{b}=6.25 \times 10^{-3}$ $\mathrm{kg} \cdot \mathrm{mm}^{3} / \mathrm{s}^{2}$ のように曲げ剛性が大きい繊維の場合には, ほとんどまっすぐな形態を維持しながら循環流れの中で 回転している.これに対し，曲げ剛性が小さくなると Fig.8 から分かるように, 計算に用いた繊維の自然状態 での形状が直線であるため, 緘維は流れに曝されてしば らくは先端がいったん曲げられるが，すぐにまっすぐな 形状に戻る $(t \leq 0.7 \mathrm{~s})$. しかし，さらに時間が経過する と今度は，繊維は常に曲がった形状を保ったままで回転 するようになる．特に曲げ剛性の小さいフレキシブルな 繊維には定常な形状や運動状態は存在しないが, 恐らく, $t \geq 1.6 \mathrm{~s}$ 以降の運動状態がこの緎維にとって定常状態に 近いものであると考えられる，なお，緘維が円弧状に変 形した場合には，まっすぐな㵶維に比べて角速度が小さ くなることも Fig.8 と Fig.10 の比較から分かる. これら 二つの曲げ剛性の中間の值を有する繊維の場合には,

Fig.9 に示すように, いったん先端付近が曲げられて円 弧状の形態になるが，次の瞬間にはすぐにまっすぐな形 状に戻るという動作を繰り返す。

以上のように，緘維の有する曲げ剛性が形態の変化に 大きな影響を及ぼすため流れ場も大きく変化する．当然 であるが，繊維が円弧状に変形して回転する場合（Fig.8) には，直線状の形態を保って回転する場合（Fig.10）に 比べて, 纎維の存在によって影響を受ける流れ場の領域 は狭くなる。ここで示した計算条件の範囲内では，長さ $1 \mathrm{~mm}$ の繊維を幅 $3 \mathrm{~mm}$ の流路の中心線の近くに置いた場 合には繊維と流路壁面との相互干涉は全く見られない，

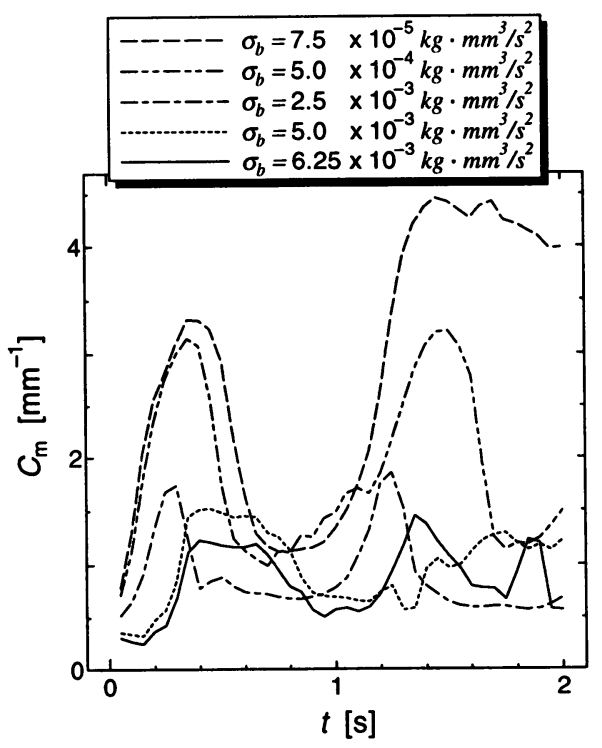

Fig.11 Effect of the bending stiffness of a fiber $\sigma_{b}$ on the evolution of the mean curvature $C_{m}$ for $\sigma_{s}=1.0 \mathrm{~kg} / \mathrm{mm} \cdot \mathrm{s}^{2}$, $\mu=1.0 \times 10^{-4} \mathrm{~kg} / \mathrm{mm} \cdot \mathrm{s}$ and $G=10 \mathrm{~s}^{-1}$. The initial position $\left(x_{0}, y_{0}\right)$ of the endpoint of a fiber is $(4.5 \mathrm{~mm}, 1.5 \mathrm{~mm})$.

これも Fig.8 10 で流路の中央部分を除き流線が壁面に平 行になっていることから明らかである.

繊維の曲率と曲げ剛性の関係を定量的に調べるために, 曲率の平均 $C_{m}$ を繊維の各分割点上における曲率 $C_{l}\left(l=1,2, \ldots, N_{f}-1\right)$ を用いて，(18)式のように定義し， その結果を Fig.11 に示す.

$$
C_{m}=\frac{1}{N_{f}-1} \sum_{l=1}^{N_{f}-1} C_{l} .
$$

Fig.11を見ても，曲げ剛性の値が小さくなるほど，䋐 維はよく曲がっていることが分かる．また，この計算時 間の範囲内では 1 点鎖線および 2 点鎖線で示す $\sigma_{b}=2.5 \times 10^{-3}$ と $5.0 \times 10^{-4} \mathrm{~kg} \cdot \mathrm{mm}^{3} / \mathrm{s}^{2}$ の場合には繊維の 曲率の変化に周期性が見られる.

\section{5. 結 論}

本研究の目的は, Peskin により開発された immersed boundary method を用いて数值計算を行い, ニュートン 流体の流れ中におけるフレキシブル緎維の運動とその周 りの流れ場の変化を明らかにすることにある. immersed boundary method とは, 伸長, 曲げ, ねじりなどの変形 を行う細長い粒子が流体内に存在する場合, 形態を変え るのに必要な力（力の線密度）が粒子の長さ方向に沿っ て分布するが，粒子の大きさ，質量が無視できると仮定 すると，その力がそのまま周りの流体要素に外力となっ て作用し，それによって流れ場が変わるという原理に基 づく方法である．また，粒子の大きさ，質量が無視でき 
るので力が作用している粒子上の各点は，その点の流速 で移動する.このようにして，粒子の変形と流れ場の変 化が互いに影響を及ぼし合うことになる。

本報告は, 一連の研究の第 1 報であり, 䋐維の変形に 要する力，その力に基づいて流体に働く外力ならびに繊 維の運動を表す基礎式 $[22,25]$ を示すとともに，これら 基礎式の数值計算に必要な離散化と流れ場に関する基䊙 式の離散化について詳細に述べた，さらに，第一段階と して, 二次元単純せん断流れ場に自然状態での曲率が 0 である繊維を一本懸濁した場合について，緘維の運動と その周りの流れ場を数值計算し，代表的な結果として瀻 維の弾性係数が緎維の伸長ひずみに及ぼす影響と曲げ剛 性が繊維の変形および流れ場に及ぼす影響を示した。た だし，繊維の変形はせん断流れの平面内における伸長と 曲げのみ考えた。 なお，せん断速度ならびに流体の粘度 の影響については掲載頁数の制限から第 2 報で報告する. 得られた結果をまとめると以下のようになる.

(1) 繊維の弾性係数が大きくなるにつれて伸長ひずみは 小さくなる.

（2）繊維の周辺には循環流れが発生し，その循環流れに よって繊維が回転しながら下流へ移動する.

（3）曲げ剛性が大きい繊維の場合には，ほとんどまっす ぐな形態を維持しながら循環流れの中で回転する。これ に対し，曲げ剛性が小さくなると，緘維は流れに曝され てしばらくは先端がいったん曲げられるが，すぐにまっ すぐな形状に戻る．しかし，さらに時間が経過すると今 度は，繊維は常に曲がった形状を保ったままで回転する ようになる．また，中程度の曲げ剛性を有する繊維の場 合には，いったん先端付近が曲げられて円弧状の形態に なるが，次の瞬間にはすぐにまっすぐな形状に戻るとい う動作を繰り返す。

（4）纎維が円弧状に変形して回転する場合には，直線状 の形態を保って回転する場合に比べて，緎維の存在によ って影響を受ける流れ場の領域は狭くなる。ここで示し た計算条件の範囲内では，長さ $1 \mathrm{~mm}$ の絨維を幅 $3 \mathrm{~mm}$ の 流路の中心線の近くに置いた場合には瀻維と流路壁面と の相互干渉は全く見られない.

ここでは，2 次元流れ中で流れ平面内で変形する緘維 について考えた. 従って，極めて制約の多い条件である. 本研究は，厚さの薄い繊維懸濁液の流れの基礎的研究と して位置付けられる．例えば，製紙工程におけるパルプ 瀻維の変形と流動の基礎的な現象を明らかにする研究. しかし,ここで用いた手法は 3 次元流れ中において 3 次 元変形する繊維の運動にも容易に拡張できるものである. ただし，数値計算の負荷は急激に増大する．また，実際 の工程で見られる多数の繊維の相互干渉を含む繊維の変 形挙動の計算も可能である.

\section{[ 付 録 ]}

(6. 2)式の被積分関数は, 繊維の曲率であり, Fig.3に 示すように $d \theta_{l}$ を定義すると，

$$
\frac{d^{2} X}{d s^{2}} \cdot n \approx \frac{d \theta_{l}}{d s},
$$

である. 一方,

$$
C=\left\|\boldsymbol{X}_{l+1}-\boldsymbol{X}_{l}\right\| \cdot\left\|\boldsymbol{X}_{l}-\boldsymbol{X}_{l-1}\right\| \sin d \theta_{l} \quad \text { とおき, }
$$

繊維の伸びならびに $d \theta_{l}$ が小さい場合を考えると，

$$
\left\|\boldsymbol{X}_{l+1}-\boldsymbol{X}_{l}\right\| \approx\left\|\boldsymbol{X}_{l}-\boldsymbol{X}_{l-1}\right\| \approx \Delta s, \quad \sin d \theta_{l} \approx d \theta_{l}
$$

であるので,

$$
C=(\Delta s)^{3} \frac{d \theta_{l}}{d s},
$$

となる. 従って,

$$
\frac{d^{2} \boldsymbol{X}}{d s^{2}} \cdot n \approx \frac{1}{(\Delta s)^{3}}\left\|\boldsymbol{X}_{l+1}-\boldsymbol{X}_{l}\right\|\left\|\boldsymbol{X}_{l}-\boldsymbol{X}_{l-1}\right\| \sin d \theta_{l}
$$

(6.2)式は(9)式のように離散化される.

\section{References}

[1] Chiba, K.; J. Text. Mach. Soc. Japan, 43, P248 (1990)

[2] Rosenberg, J., Denn, M.M., Keunings, R.; J. NonNewtonian Fluid Mech., 37, 317 (1990).

[3] Phan-Thien, N., Graham, A.L.; Rheol. Acta, 29, 433 (1990) .

[4] Phan-Thien, N., Graham, A.L.; Rheol. Acta, 30, 44 (1991).

[5] Ranganathan, S., Advani, S.G.; J. Non-Newtonian Fluid Mech., 47, 107 (1993).

[6] Altan, M.C., Rao, B.N.; J. Rheol., 39, 581 (1995).

[7] Ahmed, A., Alexandrou, A.N.; J. Non-Newtonian Fluid Mech., 55, 115 (1994).

[8] Chung, S.T., Kwon, T.H.; Polym. Eng. Sci., 35, 604 (1995).

[9] Lipscomb, G.G., Denn, M.M., Hur, D.H., Boger, D.V.; J. Non-Newtonian Fluid Mech., 26, 297 (1988).

[10] Chiba, K., Nakamura, K., Boger, D.V.; J. Non-Newtonian Fluid Mech., 35, 1 (1990).

[11] Baloch, A., Webster, M.F.; Comput. Fluids, 24, 135 (1995).

[12] Altan, M.C., Advani, S.G., Guceri, S.I., Pipes, R.G.; J. Rheol., 33, 1129 (1989).

[13] Chono, S., Makino, M.; Trans-B. Mach. Soc. Japan, 61, 3190 (1995).

[14] Ausias, G., Agassant, J.F., Vincent, M., Lafleur, P.G., Lavoie, P.A., Carreau, P.J.; J. Rheol., 36, 525 (1992).

[15] Ausias, G., Agassant, J.F., Vincent, M.; Intern. Polym. Proc., 9, 51 (1994). 
[16] Ausias, G., Vincent, M., Jarrin, J., Thermop, J.; Compos. Mater., 8, 435 (1995).

[17] Ghosh, T., Grmela, M., Carreau, P.J.; Polym. Compos., 16, 144 (1995).

[18] Grmela, M., Lafleur, P.G.; J. Chem. Phys., 109, 6956 (1998).

[19] Grmela, M., Ait-Kadi, A., Lafleur, P.G.; J. Chem. Phys., 109, 6973 (1998).

[20] Jeffery, G.B.; Proc. R. Soc., A102, 161 (1922).
[21] Peskin, C.S.; J. Comput. Phys., 25, 220 (1977).

[22] Fauci, L.J., Peskin, C.S.; J. Comput. Phys., 77, 85 (1988).

[23] Fogelson, A.L., Peskin, C.S.; J. Comput. Phys., 79, 50 (1988).

[24] Sulsky, D., Brackbill, J.U.; J. Comput. Phys., 96, 339 (1991).

[25] Stockie, J.M., Green, S.I.; J. Comput. Phys., 147, 147 (1998). 